\title{
Error Analysis of TEM-4 Dictation and Teaching Suggestions to TEM-4 Dictation
}

\author{
Xiaoguang Li' ${ }^{1}$, Yangmei $\mathrm{Li}^{2}$ \\ ${ }^{1}$ Department of Business English, School of Foreign Studies, Yangtze University, Jingzhou, China \\ ${ }^{2}$ Gong'an County No. 1 Middle School, Gong'an, China \\ Email: langue@qq.com
}

How to cite this paper: Li, X.G. and $\mathrm{Li}$, Y.M. (2016) Error Analysis of TEM-4 Dictation and Teaching Suggestions to TEM-4 Dictation. Open Journal of Social Sciences, 4, 187-193.

http://dx.doi.org/10.4236/jss.2016.411015

Received: October 30, 2016

Accepted: November 25, 2016

Published: November 28, 2016

Copyright $\odot 2016$ by authors and Scientific Research Publishing Inc. This work is licensed under the Creative

Commons Attribution International

License (CC BY 4.0).

http://creativecommons.org/licenses/by/4.0/

(c) (i) Open Access

\begin{abstract}
Dictation is an important part in Test for English Majors-4 (TEM-4) in China. By analyzing the data of the results of TEM-4 (2010), this paper classifies the error types in TEM-4 dictation and investigates the causes of these different errors. The authors hope this paper will be helpful for English teachers in the preparation of teaching TEM-4 dictation.
\end{abstract}

\section{Keywords}

TEM-4, Dictation, Error Analysis

\section{Introduction}

Test for English Majors 4 (TEM-4) is the examination for College English majors to take in the second semester of second academic year. It aims to "examine students" comprehensive ability of English language use" [1]. According to the Test Syllabus of College TEM-4, the contents are "Dictation, Listening Comprehension, Cloze, Grammar and Vocabulary, Reading Comprehension and Writing" [2]. The requirements for Diction include that "students should fully comprehend the passage and write it down word by word" and "there are few spelling and punctuation errors, the rate of which is no more than $8 \%$ ". Zou Shen et al. [3] stated that "dictation is an effective way to measure whether students grasp basic knowledge of English language, which is a comprehensive test."

As an important part of TEM-4, dictation has long been the focus for the teachers and students in the preparation for it. Many scholars have done researches on Dictation in a variety of perspectives. Li Shaoshan [4] discussed dictation in its function, nature 
and psychological processes, and put forward some advice on the teaching of dictation. Yin Wanbao [5] investigated students' errors in dictation by using questionnaires. $\mathrm{Xu}$ Jing et al. [6] summarized common errors in TEM-4 passage diction by adopting error analysis. Zou Shen et al. [7] explored the cognitive process in test-takers' dictation performance and their errors in dictation from the dimensions of cognitive processing and linguistic competence. However, the methods which were used in the past studies on TEM-4 dictation were limited in questionnaire (such as Yin Wanbao [5]) and model test (Jing Hongyu [8]). There were few studies on Dictation in TEM-4 by analyzing the English-majored undergraduate students' dictation data of the past TEM-4 exam papers.

By collecting students' Dictation answer sheet materials, in combination with the grading standards of dictation, this paper classifies the different types of errors and analyzes the causes. The conclusions will be more persuasive and will be helpful for the teachers and students to practice purposefully more on these errors.

\section{Methods}

\subsection{Subjects}

The target students (259 sophomores English-majored undergraduates) were selected randomly from 9 English major classes and would take part in the TEM-4 in April 19, 2014. Before taking this test, these students had been practicing dictation for a time and quite familiar with the formation and the grading standards of TEM-4. The target students' average age was 20 years old. The target students were 222 female sophomores English-majored undergraduates and 37 male sophomores English-majored undergraduates.

\subsection{Data Collecting}

The test paper was the past TEM-4 taken in 2010. In order to achieve the real situation of TEM-4, this test is carried out by strictly following the TEM-4 directions which require students to hand in answer sheets after finishing two listening part (Dictation and Listening Comprehension). Then, they continued the following parts of the test (Reading Comprehension and Writing).

259 answer sheets were collected. We focused our research on the data of their Dictation.

In the dictation (see Appendix 1), there were 12 sentences and 156 words. 15 clauses were divided in terms of sentence meaning.

\subsection{Data Analysis}

In College English Teaching Syllabus for English Majors [1], errors in dictation can be divided into two categories: serious errors and non-serious errors. Serious mistakes include miss writing, adding words, creating words, changing words, big shifts of dictation content, tense errors, the original one word divided into two words; non-serious errors include spelling errors of one to two words, punctuation errors, article errors, 
singular and plural errors.

On the basis of the classification of errors mentioned above, the following errors are analyzed in this paper: the individual word spelling errors, miss-writing functional words, the first letter of proper nouns capitalized and so on (see Appendix 2).

\section{Results}

On the whole, the results of the examination were not so good from the whole examination's situation. And the problems in dictation are more serious. Based on statistical data on errors in dictation in this study, we summarize the types of errors in dictation, and tried to explore the causes to errors in dictation.

\subsection{Errors in Functional Words}

According to the rules of English pronunciation, usually, the functional words are unstressed in the sentence, as the pronunciations of such words in the sentence are light, often liaison with other words, or metaphors appeared and even swallowed sound, so missing writing was easy to be occurred.

In the dictation material of this paper, the frequency of missing writing of to (1) in errors of functional words was the highest, 252 times, $97.3 \%$. For example:

1) But to (1) those who are new to (2) this system, it can sometimes be confusing.

There are two functional words in Example 1), "to (1)" and "to (2)" for being distinguished, and the number of errors in functional words were 252 times and 138 times respectively.

The error rate of other functional words (such as "a (1)", "and (1)", "it", etc.) was also very high. And the number of errors in the functional words was 21 in the 40 errors counted in Appendix 2. The main form of the error is missing writing.

\subsection{Spelling Errors of Proper Nouns}

Learners of English as a second language or foreign language often find it difficult to grasp the proper nouns, especially names, place names, professional terms, etc., and proper nouns are often spelled wrongly. In addition to understanding the corresponding relationship between the English pronunciation and spelling, students also should understand the rules of spelling proper nouns. For example, the first letter of the proper nouns in English should be capitalized. The title of this dictation was "Freshmen's Week" that was also explained in the text, and "Freshmen's Week" can be used as a proper noun. Take the fifth clause as an example:

2) Universities have something called "Freshmen's Week" for their newcomers.

Therefore, the first letters of "Freshmen's" and "Week" should be capitalized. The error rate of the two words is $95 \%$ and $92.3 \%$ respectively. And the error rate is very high, indicating that errors of spelling proper nouns for two words would occur at the same time, that is to say, if the first letter of "Freshmen" was not capitalized, so was "Week".

At the same time, we also found that the error rate of "Freshmen's" is slightly higher 
than that of "Week", which showed that spelling proper nouns of "Freshmen's" was more difficult for students to grasp than that of "Week".

\subsection{The Situation of Mastering Grammatical Knowledge}

Dictation can be used to test students' ability of mastering grammatical knowledge, as the students in TEM-4 dictation are required to write down the exact words they heard, no adding words, no making words, no changing words. The situation of students' mastering grammatical knowledge is not good. The main forms of grammatical errors include inconsistency of subject-predicate, no distinguishing singular nouns from plural nouns, tense errors. For example:

3) ... the prospect of meeting strangers in classrooms and dormitories can be worrying.

4) Don't rush into anything that you'll regret for the next three years.

In Example 3), the two words ("classrooms" and "dormitories") were the plural noun's form. The error rate of the word "dormitories" was higher than that of the word "classroom". In Example 4), most students wrote "you'll" wrongly into "you". The word "you'll" for some students was wrongly written as the two words "you will". Although the students noted the tense problem, the word "you'll" written separately as the two words "you will" was counted as non-serious errors according to the scoring criteria.

Of course, there were some errors caused by improper use of grammatical knowledge. See the following example:

5) Universities have something called "Freshmen's Week" for their newcomers.

The error rate for the words "Universities" and "Have" was $44.4 \%$ and $43.2 \%$ respectively. Through the analysis, we found that both the words ("Universities have") were wrongly written into "University has".

\section{Discussion}

We want to discuss the results from the following aspects.

The functional words are difficult for students to grasp. In Example 1), because both "to (1)" and "to (2)" were unstressed in the sentence, it was difficult for students to understand accurately the words, and "to (1)" being liaison with the front word "but" was more difficult than "to (2)" for students to grasp, so the number of errors in the functional words was more.

For the spelling errors of proper nouns, we also found that the error rate of "Freshmen's" is slightly higher than that of "Week", which showed that spelling proper nouns of "Freshmen's" was more difficult for students to grasp that that of "Week". In English, according to the English language rules, the first letter of proper nouns should be capitalized, however, in Chinese, there is no same language rules. For Chinese English-majored students, it is difficult for them to grasp this language rule (the first letter of proper nouns should be capitalized).

For the situation of mastering grammatical knowledge, In Example 3), the two words ("classrooms" and "dormitories") were the plural noun's form, while, the degree of 
mastering the word "dormitories" was more difficult than that of the word "classroom", so the error rate of the word "dormitories" was higher than that of the word "classroom". And, in Example 4), most students wrote "you'll" wrongly into "you”. In addition to the elements of weakening pronunciation for the condensed form of pronouns and auxiliary verbs in English, and "future time tense" should be used here due to the following phrase "for the next three years" from the perspective of grammar. The error rate for the words "Universities" and "have" was $44.4 \%$ and $43.2 \%$ respectively, through the analysis we found that both the words ("Universities have") were wrongly written in "University has". The students found the grammatical error: inconsistency. Because the first word "University" was wrongly written by some students, and the second word "have" was heard, so the word "have" was changed into the word "has". This point can be illustrated by the closeness of the error rate of these two errors.

\section{Teaching Suggestions to Errors in TEM-4 Dictation}

Through the error analysis of the above dictation, we propose the following teaching suggestions:

Firstly, the study on phonetic knowledge should be strengthened. The study on phonetic knowledge can help students master the rules of English pronunciation, and help them understand the special pronunciation phenomena such as liaison, weakening and swallowed sounds in English. And the targeted training to the errors in TEM-4 dictation should to be done for students to improve their ability in distinguishing these special phonetics and to improve the accuracy rate in the TEM-4 dictation.

Secondly, the study on grammar knowledge should be strengthened. Listening comprehension should be related to the study on grammar knowledge, can take the form of "intensive listening" can be used in detailed analysis of the sentence structure to understand the relevant grammar knowledge.

Thirdly, the English vocabulary should be enlarged. Vocabulary is the foundation to language learning, so students are required to master as much English vocabulary as possible, and also pay attention to the exact spelling of English words.

\section{Limitations and Suggestions for Further Research}

Though the present study has analyzed errors in TEM-4 dictation, types of errors and causes to errors inTEM-4 dictation, there are still some limitations in this study. Having the limitations in mind, suggestions for further research, therefore, can be put forward at the same time.

Firstly, being time limitation (only one TEM-4 paper) and other practical restrictions such as the subjects in the study consisted of only 259 English-majored undergraduate students in Yangtze University.

Secondly, the instrument used to investigate the errors inTEM-4 dictation is answer sheets. The study would be much better, if it were combined with other instruments such as questionnaires. More instruments should be used in investigating in the further research. 
Finally, participants in this study are the English-majored undergraduates in only one university. Students specializing in other majors can also be the subjects of future study.

Despite of the restraints of the study, it is hoped that it can offer some guidelines for further research on TEM-4 dictation.

\section{Conclusions}

This paper analyzes the errors in the dictation of Test English Majors (TEM-4), and explores errors types and causes led to errors in TEM-4 dictation. Some teaching suggestions were provided to improve students' ability in TEM-4 dictation.

Of course, the TEM-4 dictation is a test of students' English comprehensive ability. The improvement of students' ability in the English dictation is not only confined to the aspects such as phonetics, grammar and vocabulary discussed in this paper, but also the students' writing habits, writing skills, attention, psychological quality and so on. Therefore, improving students' ability in the dictation also requires a lot of dictation practice. The dictation skills are constantly summed up in order to improve the students' dictation level.

\section{References}

[1] English Group of the College Foreign Language Teaching Steering Committee (2000) College English Teaching Syllabus for English Majors. Shanghai Foreign Language Education Press, Shanghai.

[2] Syllabus Revision Group for TEM 4 (2004) Syllabus for TEM-4. Shanghai Foreign Language Education Press, Shanghai.

[3] Zou, S., Chen, H.S. and Huang, S.H. (1996) An Analysis of Test of English Majors (TEM) Four and Eight in 1995. Foreign Language World, No. 1, 55-61.

[4] Li, S.S. (2001) Dictation: An Effective Means of FL Teaching and Teaching Evaluation. Journal of PLA University of Foreign Languages, No. 4, 1-5.

[5] Yin, W.B. (2008) Investigation and Analysis of Common Mistakes in Dictation of Test for English Majors (TEM) Four. Internet Fortune, No. 8, 208-209.

[6] Xu, J., Ding, Q.H. and Huang, J.J. (2012) An Analysis of the Common Mistakes in Passage Dictation of TEM-4 by Using Error Analysis. The Science Education Articles Collects, No. $12,130,148$.

[7] Zou, S. and Kong, J.F. (2013) Dictation Project for National Test for English Majors Four in 2013-Analyses and Suggestions. Foreign Language Testing and Teaching, No. 4, 1-5.

[8] Jin, H.Y. (2011) Error Analysis and Teaching Countermeasures for Dictation in the Test of English Major Four. Journal of Chifeng College (Social Science), No. 6, 241-243. 


\section{Appendix 1. Dictation Script for the Test for English Majors 4} (TEM-4) in 2010

\begin{tabular}{ll}
\hline & \multicolumn{1}{c}{ Freshmen's Week } \\
\hline 1 & Britain has a well-respected higher education system \\
3 & And some of the top universities and research institutions in the world. \\
4 & October is usually the busiest month in the academic calendar. \\
5 & Universities have something called "Freshmen's Week" for their newcomers. \\
6 & It's a great opportunity to make new friends, \\
7 & Join lots of clubs and settle into university life. \\
8 & However, having just left the comfort of home and all your friends behind, \\
9 & The prospect of meeting strangers in classrooms and dormitories can be worrying. \\
10 & Where do you start and who should you make friends with? \\
11 & Which clubs and societies should you join? \\
12 & Luckily, there will be thousands of others in the same boat as you. \\
13 & They worry about starting their university social life on the right foot. \\
14 & So just take it all in slowly. \\
15 & Don't rush into anything that you'll regret for the next three years. \\
\hline
\end{tabular}

\section{Appendix 2. Errors Analysis (Errors Frequency: More than 100 Times)}

\begin{tabular}{cccccc}
\hline Words in script & Errors frequency & Error rate & Words in script & Errors frequency & Error rate \\
\hline a (1) & 136 & $52.5 \%$ & prospect & 170 & $65.6 \%$ \\
well-respected & 211 & $81.5 \%$ & of (4) & 143 & $55.2 \%$ \\
and (2) & 197 & $76.1 \%$ & classrooms & 180 & $69.5 \%$ \\
institutions & 143 & $55.2 \%$ & and (5) & 145 & $56 \%$ \\
to (1) & 252 & $97.3 \%$ & dormitories & 189 & $73 \%$ \\
are & 136 & $52.5 \%$ & do & 184 & $71 \%$ \\
to (2) & 138 & $53.3 \%$ & clubs & 108 & $41.7 \%$ \\
this & 140 & 54.1 & societies & 225 & $86.9 \%$ \\
it (1) & 120 & $46.3 \%$ & boat & 130 & $50.2 \%$ \\
calendar & 126 & $48.7 \%$ & as & 224 & $86.5 \%$ \\
universities (2) & 115 & $44.4 \%$ & you (4) & 112 & $43.2 \%$ \\
have & 112 & $43.2 \%$ & starting & 156 & $60.2 \%$ \\
Freshmen's & 246 & $95 \%$ & foot & 123 & $47.5 \%$ \\
Week & 239 & $92.3 \%$ & it (2) & 132 & $51 \%$ \\
their (1) & 164 & $63.3 \%$ & all (2) & 145 & $56 \%$ \\
newcomers & 218 & $84.2 \%$ & in(5) & 190 & $73.4 \%$ \\
join & 177 & $68.3 \%$ & into & 172 & $66.4 \%$ \\
into & 124 & $47.9 \%$ & that & 136 & $52.5 \%$ \\
comfort & 127 & $49 \%$ & you'll & 239 & $92.3 \%$ \\
of(3) & 221 & $85.3 \%$ & regret & 121 & $46.7 \%$ \\
\hline
\end{tabular}


Submit or recommend next manuscript to SCIRP and we will provide best service for you:

Accepting pre-submission inquiries through Email, Facebook, LinkedIn, Twitter, etc. A wide selection of journals (inclusive of 9 subjects, more than 200 journals)

Providing 24-hour high-quality service

User-friendly online submission system

Fair and swift peer-review system

Efficient typesetting and proofreading procedure

Display of the result of downloads and visits, as well as the number of cited articles

Maximum dissemination of your research work

Submit your manuscript at: http://papersubmission.scirp.org/

Orcontact jss@scirp.org 